\title{
The electronic word of mouth as a context variable in the hotel management decision-making process
}

\section{El boca-oído electrónico como variable de contexto en el proceso de toma de decisiones de gestión en hoteles}

\author{
Carmen Berné-Manero ${ }^{1}$ \\ Andreea V. Ciobanu ${ }^{1}$ \\ Marta Pedraja-Iglesias ${ }^{1}$ \\ University of Zaragoza (Spain)
}

Recibido el 24 de noviembre de 2017, aceptado el 30 de abril de 2019

Publicado online el 8 de octubre de 2019

$\mathrm{N}^{\mathrm{o}}$ de clasificación JEL: M31, C31

DOI: $10.5295 / \mathrm{cdg} .170860 \mathrm{cb}$

\begin{abstract}
:
The tourism literature claims more research regarding the electronic word-of-mouth (eWOM) impacts management, as well as the application of multidisciplinary theories, specifically in hotels. In order to fill this gap, and taking advantage of the Behavioural Reasoned Theory $(B R T)$, this research proposes and validates a model of the decision-making process of hotel managers about accepting and implementing of eWOM as a management tool. The aim is to explain this decision-making process by stages, considering eWOM characteristics as a context variable and the hotel performance as dependent variable moreover the intentions of future behaviour. A survey addressed to hotel decision-makers in Spain is used as the source of information. Applying Structural Equations Models, the results confirm the eWOM context variable as essential to obtain a better hotel performance through the motives of decision-makers, as well as these improvements do not influence the future behaviour. Therefore, the hotels must implement the eWOM management, supported by a strategic plan and trained staff.
\end{abstract}

\section{Keywords:}

Behaviour, electronic word-of-mouth, hotels, management, performance, structural equations models.

\section{Resumen:}

La literatura sobre turismo reclama más esfuerzos de investigación sobre la gestión de los impactos del boca-oído electrónico (eWOM) así como sobre la aplicación de teorías multidisciplinares, específicamente en hoteles. Para cubrir esta demanda, desde la Teoría del Comportamiento Razonado (TCR), esta investigación propone y valida un modelo integral del proceso de toma de decisiones de los hoteles sobre la aceptación e implementación del eWOM como herramienta útil para la gestión. El objetivo es ilustrar el proceso por etapas, incluyendo las características del eWOM en el modelo como variable de contexto capaz de influir positivamente en la mejora de resultados del hotel. Un cuestionario, dirigido a recoger la opinión directamente de los responsables de hoteles en España, proporciona los datos necesarios para el contraste del modelo. La aplicación de Modelos

1 Faculty of Business. Gran Vía 2, 50005, Zaragoza (Spain). cberne@unizar.es; andreeav.ciobanu@gmail.com; mpedraja@unizar.es 
The electronic word of mouth as a context variable in the hotel management decision-making process

de Ecuaciones Estructurales ofrece unos resultados que confirman el importante papel de las características del eWOM para la obtención de mejores resultados empresariales a través de las motivaciones de los decisores, así como que estas mejoras no influyen en las intenciones de comportamiento futuro. Por lo tanto, los hoteles deben incluir el eWOM en su gestión, apoyándose en un plan estratégico y contando con personal especializado.

\section{Palabras clave:}

Comportamiento, boca-oído-electrónico, hoteles, gestión, desempeño, modelos de ecuaciones estructurales. 


\section{INTRODUCTION}

The reliability of the information uploaded directly by consumers and the ability to reduce uncertainty in decision-making are two suggested reasons for considering electronic word-of-mouth (eWOM) as a useful management tool for companies in the tourism sector (Bronner and De Hoog 2011). Most prior research on this sector has focused on tourist habits, attitudes and behaviours. Despite the major impact of online reviews on the demand side, very little attention is given to the reactions of hospitality managers, so there is a dearth of information from business decision-makers on the supply side, especially regarding the impacts of the eWOM on hospitality management (Cantallops and Salvi 2014). Thus, Baka (2016) calls for more research aimed at fully incorporating eWOM into business strategy.

A critical theoretical review of the last 25 years of research on tourism WOM and eWOM by Confente (2015) stresses the importance of hotels, destinations and tourism services understanding the potential of this tool, while Schuckert et al (2015) review and analyse articles online tourism and hospitality reviews published between 2004 and 2013. Neither of these works finds more than a few manuscripts focusing on managers' responses to online customer reviews. Further research, therefore, needs to cover the issue of identifying and implementing appropriate strategies in response to customer reviews. This claim is also supported by experience, given that observation shows customers reacting favourably to responses from managers. According to Tripadvisor, highly engaged hotels (those that respond to at least $25 \%$ of the reviews they receive on TripAdvisor) achieve nearly a four times higher rate of page views, a $63 \%$ higher average popularity ranking and $30 \%$ to $40 \%$ higher traveller interaction with revenue-driving products than their non-engaged counterparts. Nevertheless, although managing eWOM communication can provide firms with competitive advantages and improve their results, the response from hotels to online comments is remarkably low (fewer than $4 \%$ are answered, according to Xie et al. 2016; Xie et al. 2017), and hospitality businesses are recommended to respond more actively to consumer comments (Wei et al. 2013). Kim et al (2015) and Xie et al (2016; 2017) shed some light in this regard by analysing secondary information from quantitative data, through sources such as Tripadvisor. These authors call for more research before making generalizations. Thus, rather than relying on quantitative data about response rates, methods that explore people's subjective experiences and opinions are needed to provide a better understanding of the managerial decision-making process. Moreover, the literature demands more research in the tourist context on the application of multidisciplinary theories, and more specifically in hotels (Jalilvand et al. 2012; Confente 2015).

The purpose of this research is to fill the observed academic gap by proposing and testing a comprehensive model of hotel managers' decision-making in relation to accepting and implementing eWOM and its capacity to influence hotel performance. With this aim in mind, the Behavioural Reasoned Theory (BRT) is considered, whose authors (Westaby et al. 2010) encouraged further studies in different research contexts to put their theory to the test.

This paper begins with a literature review, following which the working hypotheses are stated and a theoretical model is proposed. This model is tested using Structural Equation Modelling (SEM) with data collected from an online survey of hotel operators in Spain. 
Thus, the geographical context of the empirical research is the Spanish tourism sector, considered to be one of the most competitive markets in the world, although it has never before been studied for the purposes just stated. The results validate the proposed model and provide useful theoretical and practical contributions as well as guidelines for future research.

\section{BACKGROUND AND THEORETICAL MODEL}

Prior literature has studied the role played by WOM in the tourism industry. The concept of eWOM includes any comments, positive or negative, made by a potential, current, or former consumer about a product or company through the use of online media, whether before, during, or after the experience (Hennig-Thurau et al. 2004). Generally considered a means of communication, eWOM can play a significant role in customers' decision-making, and it certainly affects sales (Sparks and Browning 2011). Thus, managing online reviews is an opportunity for companies (Litvin et al. 2008), who can adapt their business models in order to offer added value (Sigala 2013).

A synthesis of 42 previous papers on WOM in the tourism industry, published in top-level marketing journals, is provided by Confente (2015). Among the reviewed papers, the author identifies five levels, according a literature review technique known as the paradigm funnel (Berthon et al. 2003): papers that are primarily empirical (level 1), papers dealing mainly with analytical methods (level 2), papers concerning specific theories (level 3 ), papers analysing or comparing epistemological suppositions and specific methodological perspectives (level 4), and overviews articles (level 5). A wide variety of themes are included in these five levels: from WOM consultation and the impact of eWOM on choice of tourism destination to understanding the factors, which motivate consumers to seek and spread WOM.

Most of the articles are empirical and use secondary data, and are aimed at exploring the influence of eWOM on consumers selecting a tourism destination. Jalilvand et al (2012), in level 2, Cheng et al (2006), in level 3, and Jalilvand and Samiei (2012), included in level 3 too, test the theory of planned behaviour with this aim. All of them find that, among tourists, eWOM positively and significantly influences the intention to visit and attitudes towards a specific tourism destination. This is a very fruitful research line, also followed by others such as Di Pietro et al (2012), Albarq (2013), and Miao (2015).

However, only a few papers empirically investigate managerial responses to online reviews and the relationship between eWOM and business performance. The five works identified at level 1 are Ye et al $(2009 ; 2011)$, which empirically investigates the impact of online consumer-generated reviews on hotel room online bookings and sales; Litvin and Hoffman (2012) which determines the moderating effect of consumer rebuttals and management responses to negative postings on travel review boards; Park and Allen (2013) which examines the processes through which luxury hotels manage online review responses, and the underlying reasons for their choices; and Sun et al (2013), which investigates the relationships between organizational commitment and WOM intentions. At level 4, Litvin et al (2008) focus their investigation on the communication between producers and consumers and among consumers. They understand eWOM as online interpersonal influence, informal communications directed at other consumers through Internet-based technology 
related to the usage or characteristics of particular goods and services and their sellers, and they affirm that encouraging good eWOM should result in enhanced business activity.

Without being included in any of the above-mentioned levels, Anderson (2012) examines the effects of online review information, such as ratings, and the number of reviews on price premium. His results confirm that an increase in the user-generated content score can improve hotel performance: positive contents enhance hotel revenues.

With a similar aim to that of Confente (2015), Schuckert et al (2015) analyse the 50 research papers on online tourism and hospitality reviews published between 2004 and 2013. Based on a keyword-driven search and a content analysis, their findings reveal that more attention has been paid to the relationship between online reviews and online buying, where online reviews are important to both sellers and buyers, and to customer satisfaction and online management. While a positive correlation is found between higher customer ratings and online sales for hotels, Shuckert et al (2015) remark on the limited validity of using the number of reviews as a proxy for real online sales by hotels. Gu and Ye (2014) is the only one of these papers which, using data retrieved from a major online travel agency in China, measures the impact of management responses on customer satisfaction, finding them to be highly effective among low-satisfaction and complaining customers. The limitations here relate to the use of overall numerical ratings, which may not be ideal customer satisfaction Indicators.

Since then, the literature has provided some advances on tourism managers' response to online reviews. Kim et al (2015) investigate the impact of the choice of approach to online review management on hotel performance. Their research uses hotel performance metrics from major online travel intermediaries and social media websites to measure the performance of a hotel affiliated with a major hotel brand, and demonstrate that online review management leads to a performance increase. Overall ratings are the most salient predictor, followed by response to negative comments. In conclusion, the authors affirm that online reviews on social media should be managed as a critical part of hotel marketing. Xie et al (2016) provide a practical model that enables hotel managers to orchestrate their social media marketing approaches and efforts towards building an optimal social media strategy. The results of their study, which focuses on the volume rather than the content of management response due to unavailability of qualitative data, indicate no significant effect of managerial response on hotel performance. However, managerial response was found to play a moderating role in how consumer eWOM affects hotel performance.

More recently, using Tripadvisor data on management responses to consumer reviews, Xie et al (2017) find that timely and lengthy responses enhance future financial performance (average revenues and occupancy rate), whereas trite, hackneyed replies do the opposite. This is an interesting study, although the authors acknowledge the limitation of its being an empirical data analysis examining only quantitative aspects of the issue.

In any event, travellers benefit from sharing their experiences through eWOM (Bilgihan et al. 2016) and influence the booking decisions of others (Cheng and Loi 2014). As a result, managing eWOM can improve hotel performance (Kim et al. 2015; Phillips et al. 2015; Xie et al. 2016).

Despite these advances on the topic, there is no prominent research on the way hotel decision-makers process these cues and implement eWOM or the potential of this tool as a context variable that might influence business performance. These are the two key research 
questions that this paper attempts to answer. The frame of reference for this study is that of behavioural theories, in particular Behavioural Reasoning Theory (BRT), which, according to Westaby (2005) and Westaby et al (2010), is superior to Ajzen's planned behaviour theory (1991), BRT postulates that, for a better understanding of decision-making and human behaviour, one must account for the specific reasons why individuals do or do not engage in an observed behaviour and that the decision-making context must be considered as a determinant of decision-maker behaviour. It also argues that intentions are directly related to behaviour and are strongly influenced by motives. The behaviour variable measures the response of the leader in terms of actions or decisions actually taken. Particularly, Westaby et al (2010)'s model explains human resources recruitment behaviour over a period $t$ to $t+1$, establishing links between reasons, global motivations and intentions.

Figure 1

\section{BRT Model}

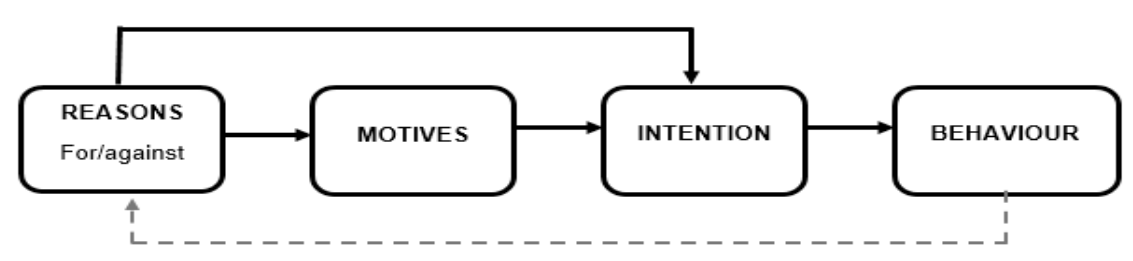

Source: Westaby et al. 2010, p. 483.

BRT has already been used in management (e.g. Westaby et al. 2010; O`Driscol et al. 2013), marketing (e.g. Briggs et al. 2010; Gupta and Arora 2017; Park et al. 2017; Ryan and Casidy 2018), and innovation adoption research (e.g. Claudy et al. 2015). This knowledge is transferred to the research context of eWOM usage by hotel decision-makers as a tool for improving business performance. The modelling proposal therefore includes relationships between reasons (prior conditions favouring or impeding the use of eWOM as a management tool), global motives (to develop the system), management behaviour (performance gains derived from changes implemented through actions following from motivations), and intentions to continue using the tool. It also includes a variable for the decision-making context: eWOM characteristics as seen from the decision-maker perspective.

From an information processing perspective, leaders attempt to find the most compelling reasons in order to build confidence into their decision-making. Attitude, subjective norms, and perceived control over the use of the information are the three criteria included in global motives; while attitude represents a person's global positive or negative evaluation toward doing the behaviour, subjective norms assess a person's global perceived social pressure from important others to engage in the behaviour (Westaby 2005). Perceived control reflects both past experiences and impediments, and anticipated consequences (Ajzen 1991; Alam and Sayuti 2011). Briggs et al (2010) support the idea that attitudes depend on reasons. O'Driscoll et al (2013), using BRT in the context 
of renewable energy systems, find that reasons in favour a certain behaviour determine attitudes. Westaby (2005) and Westaby et al (2010) find reasons as predictors of motives, including not just attitudes but subjective norms and perceived control from the point of view of leaders. Therefore, reasons are related to human motives. Transferring this idea to the hotel decision-maker within an eWOM context, the hypothesis is formulated as follows:

Hypothesis H1a: "Reasons in favour oflagainst the acceptance and use of information from eWOM have a direct influence (positive/negative) on hotel manager's global motives to accept and manage such information".

Leaders seek the most compelling reasons to increase their confidence in their decision-making and develop intentions to execute a given behaviour. Thus, leaders' reasons for and against certain behaviour are related both to their global motives and to their intentions (Westaby et al. 2010). The acceptance impacts positively on adopting information (Erkan and Evans 2016). If a hotel manager has strong reasons for accepting information received through eWOM, then he/she will also be more likely to have a positive attitude towards the use and reuse of eWOM communications. Therefore, in the present study context, the hypothesis is formulated as follows:

Hypothesis H1b: "Reasons in favour of/against the acceptance and use of information from eWOM have a direct influence (positive/negative) on the intention by hotel management to accept and manage such information".

The literature divides the eWOM variable into three dimensions: quality, authority and credibility. According to Rieh (2002), at an operational level, quality is identified as the extent to which users consider the information useful, good, current, and accurate; authority (cognitive) is operationalized as the extent to which users think they can rely on the information. In the eWOM context, users with authority are perceived as experts and positive influencers (Wangenheim and Bayon 2004). Source and information credibility are very important in the travel industry (Bronner and De Hoog 2016). In the online context, the credibility of reviews influences beliefs, attitudes and intentions (Lu and Stepchenkova 2012). The reliability of the source and the content generated by users influence the acceptance and use of eWOM (Martin and Lueg 2013), which may, in turn, directly influence the credibility and adoption of eWOM (Cheung and Thadani 2012). The quality of eWOM information drawn from online opinions is an important indicator of source credibility (Filieri 2015). Credibility is defined as an individual assessment of whether information is reliable and trustworthy, according to the receiver's own expertise and knowledge (Rieh 2010). The eWOM communication is a determinant of decision-maker motivations, on which it has a positive effect (Rieh 2002). eWOM communication influences the attitudes and confidence of travellers (Mauri and Minazzi 2013; Liu and Park 2015). Thus, the characteristics of eWOM, as perceived by managers, should have a direct, positive influence on their global motives, leading to the following hypothesis.

Hypothesis H2: "The perceived characteristics (quality, authority, and credibility) of the eWOM have a direct, positive influence on the global motives for the use of such information by hotel management".

People increase their intention to act in a specific way if they have a favourable attitude toward the outcome (Chen and Tung 2014). BRT stresses that the motives of deci- 
sion-makers for certain behaviour are determinant of their intentions. Therefore, motives are relatively broad substantive factors that consistently influence intentions across diverse behavioural domains (Westaby et al. 2010). O'Driscoll et al (2013) affirm that attitudes, as a component of motives, influence intentions. Motives positively influence the adoption of information (Erkan and Evans 2016).

The components of motives have been discovered as key constructs for predicting the future intention to travel (Martin et al. 2011), to visit a particular destination (Jalilvand et al. 2012), or to repeat book a hotel (Chen and Tung 2014; Teng et al. 2014). They are strongly related to the future intentions of travellers who seek recommendations online (Casaló et al. 2011; Liang and Lim 2011). These studies show the impact of eWOM communication on the behaviour of tourists and the observed relationship can be transferred to the managerial context. Thus, managers' motives will be a potential driver of future usage intention, which leads to the following hypothesis.

Hypothesis H3a: "Global motives regarding eWOM communication (attitude, subjective norms, and perceived control) have a direct, positive effect on the intentions of hotel managers”.

The BRT postulates motives as potential predictors of subsequent behaviour (Westaby 2005; Westaby et al. 2010). The predicted variable is performance in the context of this work, which deals with the business results obtained through the implementation of strategic and tactical changes aimed at achieving value co-creation, and other perceived advantages deriving from the comments, complaints, suggestions, and assessments contained in online reviews. The decision-maker understands these actions as positive changes in the business results. Therefore, managers' motives, attitudes, subjective norms, and perceived control over a decision-making process, should positively affect the business in terms of better performance indicator scores.

Hypothesis H3b:" Global motives regarding eWOM communication (attitudes, subjective norms, and perceived control) have a direct and positive effect on hotel performance".

The achieved performance will, in turn, influence managers' intentions for future usage of the tool (Chen and Tung 2014). Accordingly, improved performance should reinforce future eWOM management intentions because the decision-maker will feel encouraged to repeat prior decisions. This cause-effect relationship has already been argued to exist in the context of WOM (e.g. Huang et al. 2011).

Hypothesis H4. "Hotel performance has a direct, positive influence on future eWOM management intentions".

On the basis of all these considerations, we propose a comprehensive theoretical model to demonstrate the relationship between eWOM implementation and hotel business performance (eWIP). 
Figure 2

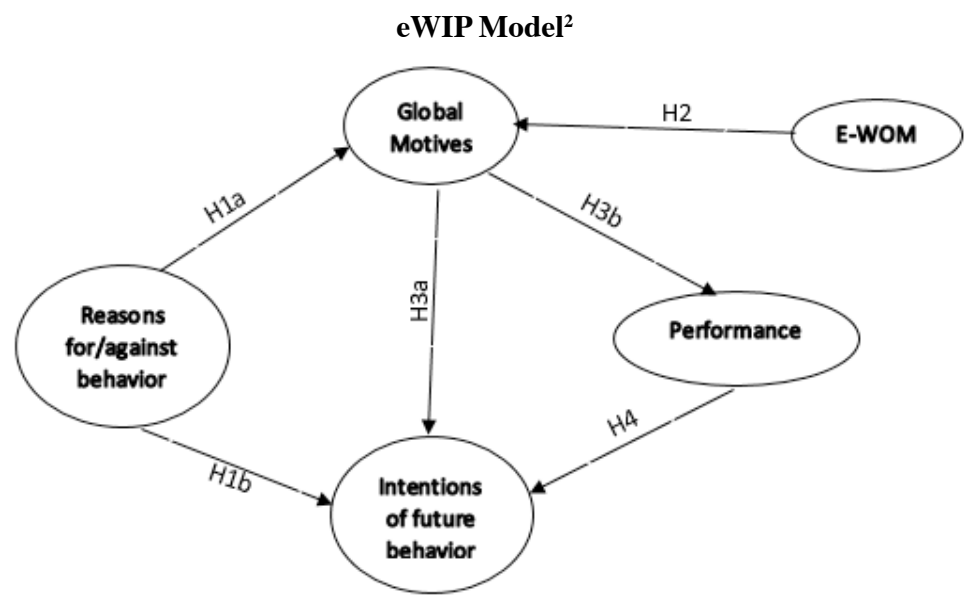

Source: Proposed by the authors.

\section{METHODOLOGY}

In order to check the cause-effect model in a true context, a quantitative method was chosen. With the aim to control the quality of the procedure, it will be checked the usual evaluation criteria, such as content and discriminant validity, reliability and goodness of fit index. The following sub-sections explain the development of the questionnaire, and the measurement scales used; they also present a description of the sample, how the data were collected, and how they are analysed.

\subsection{Measure}

The following sub-sections describe the questionnaire design, the measurement scales used, the study sample, and how the data were collected and analysed. Prior to its distribution, the questionnaire was pre-tested on three professional and three academic experts. It begins with a filter question on the use or non-use of eWOM as a management tool. The first set of questions captures reasons for and against eWOM acceptance and usage, while the subsequent sets focus on the remaining theoretical model variables. The last section collects respondents' demographic characteristics and hotel performance data.

An 11-point Likert scale was used to measure all the variables involved in the theoretical model (see Table 1. Variables and items. Own elaboration), from 0 , completely disagree, to 10 , completely agree, with the statement. The scale items are based on previous literature in order to preserve content validity. Items relating to reasons for and against the use of eWOM in hotel decision-making

2 Global Motives and eWOM are postulated as second order dimensions, each one composed by other three first order dimensions. 
are based on Westaby (2005) and Westaby et al (2010). The eWOM communication characteristics (quality, credibility, and authority) were evaluated on scales used by other authors and adapted to this context. eWOM quality was measured through four items based on Hsu et al (2006), Kim et al (2008), and Casaló et al (2011); credibility through three items based on scales used in Venkatesh and Davis (1996), Flavian et al (2006), and Casaló et al (2011); authority through the five items supported by Bansal and Voyer (2000) and Wangenheim and Bayon (2004); global motives (namely attitude, subjective norms, and perceived control) through three attitude items adapted from Yu et al (2005) and Hsu et al (2006), four subjective norms taken from Fishbein and Ajzen (1975) and Venkatesh et al (2003), and three perceived control items extracted from Ajzen (1991), Riemenschneider et al (2003), and Kraft et al (2005). Policy-makers' intention to accept and use eWOM information was measured through three items taken from Fishbein and Ajzen (1975), Westaby et al (2010), Davis et al (1989), and Venkatesh and Davis (2000). The five items used to measure effective use of eWOM as a management tool were based on Westaby et al (2010).

Table 1

Variables and items

\begin{tabular}{|c|c|c|c|}
\hline \multicolumn{2}{|c|}{ VARIABLES } & Acronyms & Items $^{\mathrm{a}}$ \\
\hline \multirow{16}{*}{$\begin{array}{l}\mathscr{0} \\
\tilde{0} \\
\mathscr{0} \\
\tilde{\Xi} \\
\mathscr{1}\end{array}$} & \multirow{10}{*}{ 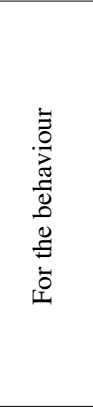 } & RFOR1 & Innovate and develop new products/services \\
\hline & & RFOR2 & Improve current products/services \\
\hline & & RFOR3 & Provide profits for the organization \\
\hline & & RFOR4 & Improve the relationship with customers \\
\hline & & RFOR5 & Obtain the loyalty of customers \\
\hline & & RFOR6 & Acquire new customers \\
\hline & & RFOR7 & Promote online customer participation \\
\hline & & RFOR8 & Create greater satisfaction for customers \\
\hline & & RFOR9 & Because the customer's opinion is important to us \\
\hline & & RFOR10 & Because the competition uses it \\
\hline & \multirow{6}{*}{ 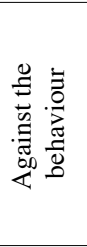 } & RAGS1 & We don't have time to read customers' opinions \\
\hline & & RAGS2 & The risk of making changes in management is too great \\
\hline & & RAGS3 & It requires considerable physical and intellectual effort \\
\hline & & RAGS4 & It requires high financial costs \\
\hline & & RAGS5 & It would not provide us with profits \\
\hline & & RAGS6 & It is hard to please all customers \\
\hline \multirow{12}{*}{$\sum_{0}$} & \multirow{4}{*}{$\stackrel{\gtrsim}{\stackrel{\Xi}{\Xi}}$} & QUAL1 & I think that eWOM provides information of excellence \\
\hline & & QUAL2 & I think that eWOM provides information that the company needs \\
\hline & & QUAL3 & I think that eWOM provides very current information \\
\hline & & QUAL4 & I think that eWOM provides very useful information \\
\hline & \multirow{3}{*}{ 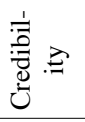 } & CRDB1 & I think that the customers who provide eWOM information are legitimate \\
\hline & & CRDB2 & I think that the eWOM information offered by customers is genuine \\
\hline & & CRDB3 & I think that the eWOM information from customers is completely reliable \\
\hline & \multirow{5}{*}{ 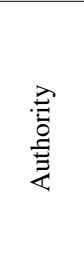 } & AUTH1 & $\begin{array}{l}\text { I think that it is important that customers who offer eWOM information have } \\
\text { experience in hotel accommodations }\end{array}$ \\
\hline & & AUTH2 & $\begin{array}{l}\text { I think that the opinions of existing customers are much more important than the } \\
\text { opinions of potential customers }\end{array}$ \\
\hline & & AUTH3 & The majority of online opinions have an influence on my management style \\
\hline & & AUTH4 & The majority of online opinions make me think about my decision-making at the hotel \\
\hline & & AUTH5 & The majority of online opinions have an influence on my management decisions \\
\hline
\end{tabular}




\begin{tabular}{|c|c|c|c|}
\hline \multirow{10}{*}{ 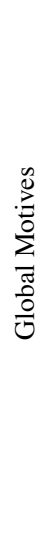 } & \multirow{3}{*}{ 异 } & ATTI1 & I think that using eWOM is very good for my hotel \\
\hline & & ATTI2 & I think that using eWOM facilitates obtaining better results \\
\hline & & ATTI3 & I have a very positive opinion about the use of eWOM \\
\hline & \multirow{4}{*}{ 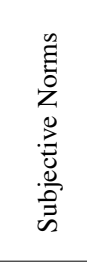 } & SNOR1 & $\begin{array}{l}\text { Everyone who is important to the development of my business thinks that it is } \\
\text { relevant to use eWOM to improve management of the hotel }\end{array}$ \\
\hline & & SNOR2 & $\begin{array}{l}\text { Everyone who has an influence on my behaviour as a manager thinks that I have } \\
\text { to use eWOM to improve management of the hotel }\end{array}$ \\
\hline & & SNOR3 & Staff supports the use of eWOM to improve management \\
\hline & & SNOR4 & $\begin{array}{l}\text { In the hospitality industry, executives who use eWOM to improve the manage- } \\
\text { ment of a hotel are perceived of as more competent than those who do not }\end{array}$ \\
\hline & \multirow{3}{*}{$\begin{array}{l}\vec{D} \\
\stackrel{D}{0} \\
\stackrel{0}{0} \\
\stackrel{0}{0} \\
0\end{array}$} & PCTR1 & The eWOM use is very easy for us \\
\hline & & PCTR2 & We control eWOM system completely \\
\hline & & PCTR3 & $\begin{array}{l}\text { Whether or not the data received through eWOM is used is always a personal } \\
\text { choice (personal control) }\end{array}$ \\
\hline \multirow{3}{*}{\multicolumn{2}{|c|}{ 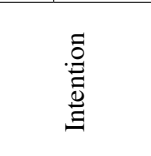 }} & INTA1 & I plan to continue using eWOM to make management decisions \\
\hline & & INTA2 & My intention is to continue using eWOM to improve the range of hotel services \\
\hline & & INTA3 & $\begin{array}{l}\text { I will definitely continue to use eWOM to improve management of the hotel in } \\
\text { the future }\end{array}$ \\
\hline \multirow{5}{*}{\multicolumn{2}{|c|}{ 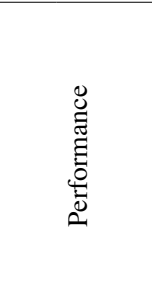 }} & PERF1 & $\begin{array}{l}\text { A lot of changes are implemented at my hotel as a result of complaints received } \\
\text { online }\end{array}$ \\
\hline & & PERF2 & A lot of changes implemented at my hotel arise from online suggestions \\
\hline & & PERF3 & A lot of changes are implemented at my hotel as a result of online reviews \\
\hline & & PERF4 & $\begin{array}{l}\text { My hotel implements many changes based on the assessments of our services } \\
\text { made by customers }\end{array}$ \\
\hline & & PERF5 & $\begin{array}{l}\text { The use of eWOM is extremely useful in the decision-making process of the } \\
\text { hotel }\end{array}$ \\
\hline
\end{tabular}

a. Items in italics will be removed after undergoing a process of purification (Cronbach's Alpha $<0,7)$. SPSS 18. Source: Own elaboration.

\subsection{Sample}

A structured survey was developed to explore digital technologies management among hotel decision-makers in Spain. Respondents had to be significantly involved in decisions concerning digital technologies in a hotel. Given that the target population for the survey is specific hotel staff members with a high level of responsibility and commitment, the respondents exhibited various characteristics of a "hard-to-reach" population (Marpsat and Razafindratsima 2010). Although it is desirable to obtain a representative sample to allow inferences to be drawn from the results (Faugier and Sargeant 1997), the described circumstances make this objective difficult to achieve. In such cases, Camisón and Villar (2012) justify a response rate of $8.1 \%$ and Brettel et al (2012) of $11 \%$. In this case, the response rate is $13.4 \%$, which is common in industrial market surveys (Camisón and Villar 2014), is in line with previous research in similar contexts (e.g. Chan 2013; Kim et al. 2015), and with expectations for a difficult-to-access population. Table 2 shows the technical data of the survey. 
Table 2

Technical survey

\begin{tabular}{l|l}
\hline Thematic and Geographical Scope & 9,641 hotels in Spain in 2013 \\
\hline Accesible And Respondent Population & 1,000 hotel decision-makers \\
\hline Collection Method and Date & $\begin{array}{l}\text { Questionnaire self-administered by e-mail (Google } \\
\text { Forms); August-October } 2013\end{array}$ \\
\hline Sampling Procedure & $\begin{array}{l}\text { Convenience sampling. The survey was distributed to } \\
100 \% \text { of the accessible base }\end{array}$ \\
\hline Sample Size & 134 valid questionnaires \\
\hline
\end{tabular}

Source: Own elaboration.

The demographic profiles of the respondents show a slightly higher rate of male than female participation (53.2\% and $46.8 \%$ respectively). The majority age group $(55.3 \%)$ is between 31 and 45 and the next largest (34\%) 46-60. Over 70\% of the sample members are university or college educated. This matches the socio-demographic profile of Internet users identified by the Telecommunication Observatory and Information Society (TOIS 2014). Over $70 \%$ of the respondents hold the position of Managing Director or Manager, $10.6 \%$ are senior accounting or customer service executives, $9.5 \%$ are heads of reception, and the remainder are Marketing Directors (8.7\%).

In terms of employees under their authority, $48.9 \%$ of the respondents have up to 10 employees, $23.4 \%$ have 11 to $20,9.6 \%$ have 21 to 30 , and the remaining $9.5 \%$ have 31 or more. As far as hotel category is concerned, the sample includes 46.8\% 4-star, $22.3 \%$ 3 -star, 18\% 2-star and 5.3\% 1-star hotels. The sample does not include respondents representing 5-star hotels, which is in line with their low presence in the market (from $1,07 \%$ to $2 \%$ in the last six years, according Statista.com). Nevertheless, they just cover the $1,07 \%$ of the entire population. Most of the respondents (representing four and three star hotels) are national leaders in higher occupancy rates (INE 2014). 63\% of the sample comprises independent hotels, while the rest belong to chains. Overall penetration by chain hotels remains constant at approximately 33\% in Spain according to the last report in 2017 (Horwath 2018). The sample covers 34 of the 50 Spanish provinces (almost 70\%) including all the coastal provinces and the most densely populated (Madrid and Barcelona).

$84 \%$ of the hotels represented facilitate eWOM communications via a website. Of those hotels that do use eWOM, 72.3\% also rely on it as a management tool. A small number of respondents report the non-use of eWOM; this, despite its positive coefficient, makes testing the model impossible for this subgroup. Therefore, hypotheses $\mathrm{H} 1 \mathrm{a}$ and $\mathrm{H} 1 \mathrm{~b}$ will be tested only in relation to reasons in favour of the behaviour.

The most common reason given to justify non-use of eWOM is the difficulty of pleasing all customers, which would imply a management failure. This is confirmed by the second and third most frequently mentioned reasons: high financial costs and lack of time. $1 \%$ of the hotels represented in the sample and their decision-makers make no use of any web 2.0 communication tools, and can therefore gain no advantage or differentiation through 
this means. This behaviour denies them the opportunity to learn from customer opinions and may have a negative influence on repurchase intentions, while also harming the reputation of the hotel (Mauri and Minazzi 2013).

The characteristics of the hotels (both users and non-users of eWOM) are generally homogeneous across the whole sample. In both groups of respondents there is a predominance of 4-star hotel managers with a degree in higher education. An independent samples t-test revealed significant differences with respect to future intentions, on which the coefficient was significantly higher on average for users of eWOM as a management tool.

\subsection{Data collection and analysis}

The Spanish National Institute of Statistics (INE 2014) lists 9.641 hotel establishments of all categories (from 1 to 5 stars; including chain-affiliated hotels) across all Spanish regions in 2013. To maximize the effectiveness of the contact, a personal email address was included as a prerequisite in the study population. Contacts were located through yellowpages.com. The number of potential respondents was thus reduced to 1,000 representing 1,000 hotels. The survey was sent to all the email addresses in a convenience sample. The first wave of contacts was made in August, with a follow-up in October. Some emails were rejected by the system because the address was incorrect.

The model was tested using Partial Least Squares (PLS) Structural Equations Modelling (SEM) techniques, and the SmartPLS 3.2.3 statistical package. The reason for this choice of methodology was to enable the prediction of latent variables through Ordinary Least Squares (OLS) and Principal Components Analysis (ACP) and thus explain the variance of the independent variables. This technique, which is becoming common in marketing research (Kim and Park 2013), is particularly suitable for small samples. The increasing use of PLS in predictive research models, moreover, underlines the development of a nascent theory (Barclay et al. 1995). It is particularly appropriate in models where latent variables are measured indirectly through multiple indicators (Wold 1985). An additional advantage is that it does not require a particular distribution of the variables (Chin 1998) and is therefore a useful alternative to the more restrictive maximum likelihood approach (Fornell and Bookstein 1982).

\section{RESULTS}

The full structural model includes nine first-order measurement models (Quality, Credibility, Authority, Attitude, Subjective Norms, Perceived Control, Reasons, Intentions and Performance) and two second-order measurement models (eWOM and Global Motives).

Methodological validity was confirmed by means of a convergent validity check through confirmatory factor analysis (AVE > 0.5) (Fornell and Larcker 1981), an individual reliability check (standardized load factor, $\Lambda>0.7)$ and an internal consistency check (Cronbach's Alpha > 0.7 and IFC >0.6) (Nunnally 1978) (See Table 3). 
Table 3

Results of first order measurement models

\begin{tabular}{|c|c|c|c|c|c|c|}
\hline DIMENSION & INDICATOR & $\Lambda$ & t-value ${ }^{a}$ & $\begin{array}{c}\text { Cronbach } \\
\text { Alpha }\end{array}$ & IFC & AVE \\
\hline \multirow{6}{*}{ Reasons } & RFOR1 & 0.71 & 10.25 & \multirow{6}{*}{0.85} & \multirow{6}{*}{0.89} & \multirow{6}{*}{0.58} \\
\hline & RFOR2 & 0.74 & 8.66 & & & \\
\hline & RFOR3 & 0.84 & 26.30 & & & \\
\hline & RFOR4 & 0.84 & 15.67 & & & \\
\hline & RFOR5 & 0.71 & 8.63 & & & \\
\hline & RFOR9 & 0.71 & 5.78 & & & \\
\hline \multirow{4}{*}{ Quality } & QUAL1 & 0.87 & 22.35 & \multirow{4}{*}{0.91} & \multirow{4}{*}{0.94} & \multirow{4}{*}{0.79} \\
\hline & QUAL2 & 0.94 & 41.72 & & & \\
\hline & QUAL3 & 0.86 & 14.38 & & & \\
\hline & QUAL4 & 0.88 & 30.15 & & & \\
\hline \multirow{3}{*}{ Credibility } & CRDB1 & 0.95 & 57.42 & \multirow{3}{*}{0.95} & \multirow{3}{*}{0.97} & \multirow{3}{*}{0.91} \\
\hline & CRDB2 & 0.95 & 33.34 & & & \\
\hline & CRDB3 & 0.96 & 43.34 & & & \\
\hline \multirow{3}{*}{ Authority } & AUTH3 & 0.87 & 17.50 & \multirow{3}{*}{0.89} & \multirow{3}{*}{0.93} & \multirow{3}{*}{0.82} \\
\hline & AUTH4 & 0.90 & 27.19 & & & \\
\hline & AUTH5 & 0.94 & 39.23 & & & \\
\hline \multirow{3}{*}{ Attitudes } & ATTI1 & 0.92 & 43.48 & \multirow{3}{*}{0.81} & \multirow{3}{*}{0.89} & \multirow{3}{*}{0.73} \\
\hline & ATTI2 & 0.86 & 22.47 & & & \\
\hline & ATTI3 & 0.77 & 11.52 & & & \\
\hline \multirow{3}{*}{ Subjective Norms } & SNOR1 & 0.85 & 18.19 & \multirow{3}{*}{0.85} & \multirow{3}{*}{0.91} & \multirow{3}{*}{0.77} \\
\hline & SNOR2 & 0.90 & 29.54 & & & \\
\hline & SNOR3 & 0.88 & 26.92 & & & \\
\hline \multirow{3}{*}{ Perceived Control } & PCTR1 & 0.79 & 7.84 & \multirow{3}{*}{0.69} & \multirow{3}{*}{0.83} & \multirow{3}{*}{0.62} \\
\hline & PCTR2 & 0.77 & 6.16 & & & \\
\hline & PCTR3 & 0.80 & 11.53 & & & \\
\hline \multirow{5}{*}{ Performance } & PERF1 & 0.90 & 10.06 & & & \\
\hline & PERF2 & 0.91 & 8.64 & & & \\
\hline & PERF3 & 0.91 & 10.07 & 0.93 & 0.95 & 0.78 \\
\hline & PERF4 & 0.89 & 8.64 & & & \\
\hline & PERF5 & 0.79 & 8.76 & & & \\
\hline & INTA1 & 0.93 & 38.29 & & & \\
\hline Intentions & INTA2 & 0.92 & 21.92 & 0.93 & 0.95 & 0.87 \\
\hline & INTA3 & 0.96 & 67.62 & & & \\
\hline
\end{tabular}

a Significant coefficients at a level of $95 \%$.

Source: Own elaboration.

Table 4 presents the results of the full model estimation including the second-order measurement models; the first-order factors embedded in the second order factor, eWOM, are Quality, Credibility and Authority, where respondents consider Quality as the first most relevant, and Authority as the second. These results are in line with the obtained by Huang et al (2011). The second-order latent variable, Global Motives, is a composite of the firstorder factors of Attitude, Subjective Norms and Perceived Control, with this last parameter having the lowest estimate. 
Table 4

Results of eWIP model, including second order measurement models

\begin{tabular}{|c|c|c|c|c|c|c|}
\hline DIMENSION & $\begin{array}{l}\text { INDICATOR/DI- } \\
\text { MENSION }\end{array}$ & $\kappa$ & $\mathrm{t}$-value $\mathrm{e}^{\mathrm{a}}$ & $\begin{array}{l}\text { Cronbach } \\
\text { Alpha }\end{array}$ & $\mathrm{IFC} / \mathrm{CFC}$ & AVE \\
\hline Reasons & $\begin{array}{l}\text { RFOR1 } \\
\text { RFOR2 } \\
\text { RFOR3 } \\
\text { RFOR4 } \\
\text { RFOR5 } \\
\text { RFOR9 }\end{array}$ & $\begin{array}{l}0.70 \\
0.75 \\
0.84 \\
0.84 \\
0.70 \\
0.71\end{array}$ & $\begin{array}{c}9.93 \\
9.25 \\
25.91 \\
17.03 \\
8.51 \\
6.07 \\
\end{array}$ & 0.85 & 0.89 & 0.58 \\
\hline \multirow{3}{*}{ eWOM } & Quality & 0.90 & 33.52 & \multirow{3}{*}{0.75} & \multirow{3}{*}{0.85} & \multirow{3}{*}{0.66} \\
\hline & Credibility & 0.66 & 5.24 & & & \\
\hline & Authority & 0.85 & 21.73 & & & \\
\hline \multirow{3}{*}{$\begin{array}{l}\text { Global } \\
\text { Motives }\end{array}$} & Attitudes & 0.89 & 45.56 & \multirow{3}{*}{0.79} & \multirow{3}{*}{0.87} & \multirow{3}{*}{0.70} \\
\hline & Subjective Norms & 0.89 & 32.30 & & & \\
\hline & Perceived Control & 0.72 & 8.14 & & & \\
\hline Performance & $\begin{array}{l}\text { PERF1 } \\
\text { PERF2 } \\
\text { PERF3 } \\
\text { PERF4 } \\
\text { PERF5 }\end{array}$ & $\begin{array}{l}0.89 \\
0.90 \\
0.90 \\
0.88 \\
0.81 \\
\end{array}$ & $\begin{array}{c}9.09 \\
7.63 \\
8.38 \\
7.31 \\
14.44 \\
\end{array}$ & 0.93 & 0.94 & 0.77 \\
\hline Intentions & $\begin{array}{l}\text { INTA1 } \\
\text { INTA2 } \\
\text { INTA3 }\end{array}$ & $\begin{array}{l}0.93 \\
0.92 \\
0.95\end{array}$ & $\begin{array}{l}38.16 \\
25.28 \\
65.03\end{array}$ & 0.93 & 0.95 & 0.88 \\
\hline
\end{tabular}

a Significant coefficients at a level of $95 \%$.

Source: Own elaboration.

The AVE was assessed to evaluate discriminant validity, which indicates the degree of dissimilarity between a given construct and any other (Kim and Park 2013) and must exceed 0.5 to validate a construct (Chin 1998).

In Table 5 the square root of the AVE is indicated by the values shown in bold type along the diagonal, which exceeded the off-diagonal correlations between the constructs, thereby providing further proof of discriminant validity. 
Table 5

Discriminant validity

\begin{tabular}{c|c|c|c|c|c}
\hline & Intentions & Global Motives & Performance & Reasons & eWOM \\
\hline Intentions & $\mathbf{0 . 9 4}$ & & & & \\
\hline Global Motives & 0.72 & $\mathbf{0 . 8 4}$ & & & \\
\hline Performance & 0.45 & 0.53 & $\mathbf{0 . 8 8}$ & & \\
\hline Reasons & 0.72 & 0.62 & 0.40 & $\mathbf{0 . 7 6}$ & \\
\hline eWOM & 0.55 & 0.70 & 0.29 & 0.41 & $\mathbf{0 . 8 1}$ \\
\hline
\end{tabular}

Source: Own elaboration.

Table 6 presents the goodness of fit index values, which validate the structural model. These results support all the hypotheses except H4: Hotel Performance is not found to have a significant influence on future eWOM management intentions. This result conflicts with the arguments made by Huang et al (2011) regarding WOM. This suggests that future behavioural intentions do not depend on improvements derived from eWOM management. Rather, the fact that the three Intentions indicators show averages higher than 0.7 suggests that intentions to continue using the tool can be logically assumed. With this exception, the findings for the decision-making process under verification have been shown to coincide with those of Rieh (2002), Westaby (2005; 2010), O'Driscoll et al (2013), Chen and Tung (2014) and Erkan and Evans (2016), and to support previous tourism sector research based on behavioural theories (Cheng et al. 2006; Jalilvand and Samiei 2012; Jalilvand et al. 2012).

Table 6

\section{Goodness of fit index}

\begin{tabular}{|l|c|c|}
\cline { 2 - 3 } \multicolumn{1}{l|}{} & $\beta$ & t- value $^{\mathrm{a}}$ \\
\hline H1a. Reasons $\rightarrow$ Global Motives & 0.40 & 5.14 \\
H1b. Reasons $\rightarrow$ Intentions & 0.44 & 4.26 \\
H2a. Global Motives $\rightarrow$ Intentions & 0.42 & 3.53 \\
H2b. Global Motives $\rightarrow$ Performance & 0.53 & 6.42 \\
H3. eWOM $\rightarrow$ Global Motives & 0.54 & 8.02 \\
H4. Performance $\rightarrow$ Intentions & 0.04 & 0.42 \\
\hline $\mathrm{R}^{2}$ (Global Motives) $=0.62$ & $\mathrm{Q}^{2}$ (Global Motives) $=0.38$ & \\
$\mathrm{R}^{2}$ (Performance) $=0.28$ & $\mathrm{Q}^{2}$ (Performance) $=0.15$ & \\
$\mathrm{R}^{2}$ (Intentions) $=0.64$ & $\mathrm{Q}^{2}$ (Intentions) $=0.49$ & \\
\hline
\end{tabular}

a Significant coefficients at a level of $95 \%$.

Source: Own elaboration. 
The $\mathrm{R}^{2}$ values showing the predictive accuracy of the eWIP model explains $62 \%$ of the variance in respondents' Global Motives, 28\% of that in Performance and 64\% of that in future Intentions Moreover, the individual Stone-Geisser's $\mathrm{Q}^{2}$ values for each construct are all positive (Chin 1998), thus guaranteeing the predictive relevance of the model. Therefore, the eWIP model is validated.

The strongest relationships that emerge are between eWOM and Global Motives and between this latter and Performance. Furthermore, estimation of the eWIP model shows not only direct but also three indirect effects on the dependent variables (shown in Figure 3. eWIP model results: direct and indirect effects. Source: Own elaboration). They are from Reasons variable and from eWOM variable towards performance (according to findings by Xie et al. 2016), and on Intentions (Table 7). These effects support the direct cause-effect relationships established between the variables through the hypotheses reinforcing the role of cause variables.

Table 7

eWIP model results. Indirect effects

\begin{tabular}{l|c|c}
\hline & $\beta$ & t- value $^{\mathrm{a}}$ \\
\hline Reasons $\rightarrow$ Performance & 0.21 & 3.93 \\
Reasons $\rightarrow$ Intentions & 0,18 & 3.42 \\
eWOM $\rightarrow$ Intentions & 0.24 & 3.57 \\
eWOM $\rightarrow$ Performance & 0.28 & 4.65 \\
\hline
\end{tabular}

a. Significant coefficients at a level of $95 \%$.

Source: Own elaboration.

Figure 3

eWIP model results: direct and indirect effects

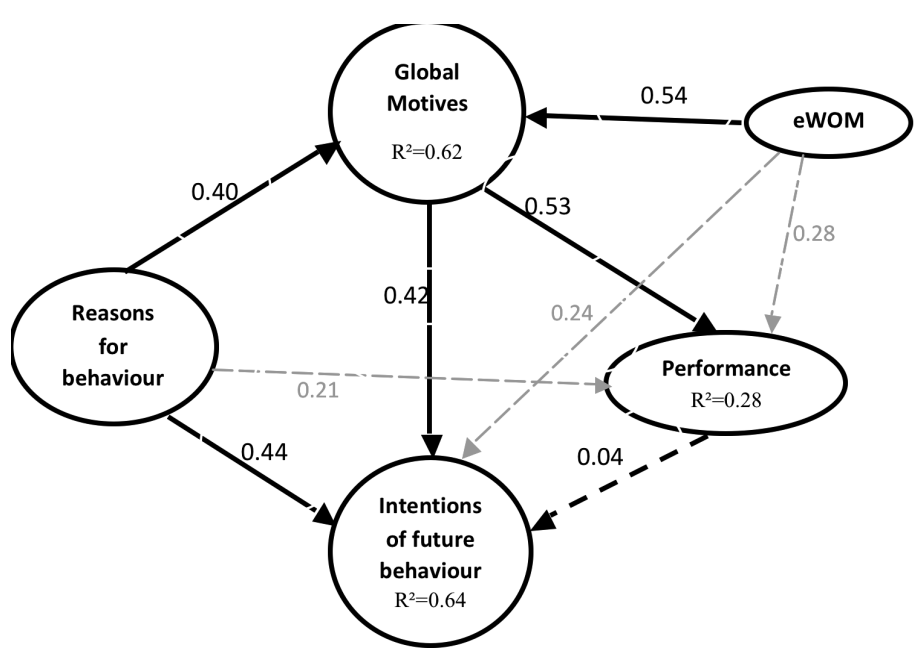

Source: Own elaboration. 


\section{DISCUSSION AND CONCLUSIONS}

The theoretical and practical contributions of this research are, first of all, that it adds value to prior knowledge on a topic that deserves more attention: the decision-making process about the use eWOM communication and the impact of this tool on business performance in the hotel industry. In an attempt to overcome some of the acknowledged shortcomings in previous studies, this paper considers the hotel decision-maker perspective, using primary data, on different kinds of hotels, not only those affiliated to major hotel chains, across a whole country, and not just one city.

In theoretical terms, this paper has contributed to by filling an observed gap in the eWOM and tourism research literature. The results support the BRT as a multidisciplinary theory, thereby confirming the importance of including a context variable as recommended by Westaby et al. (2010) when transferring the theory to other research fields.

It is also the first time that the decision-maker's perspective is considered in specialist eWOM and tourism literature. The study posed two questions: how hotel decision-makers process the acceptance and implementation of eWOM and, how this tool might act as a context variable with the potential to influence business performance. The two issues were addressed by justifying and validating a comprehensive model of the decision-making process surrounding the acceptance, implementation and derived business results of the eWOM, and testing it in a specific sector (the hotel industry). This general model can be used in both for macro- and micro-level analysis.

Thus, one very important finding is that hotel performance improvements are a direct consequence of Global Motives (direct cause-effect relationship), which are, in turn, influenced by eWOM characteristics. Moreover, both Performance and Intentions are influenced indirectly by eWOM, as perceived by hotel decision-makers.

Some practical implications can be drawn from an analysis of the survey respondents. The majority facilitate eWOM communication with their customers through a website, and accept eWOM as a management tool. Shuckert et al (2015) report that, by the end of 2013 , over $70 \%$ of the hotels in Hong Kong had adopted online response management; therefore, this is not only a global trend rather a global necessity. The application of eWOM in the hospitality industry is flourishing and its influence makes it mandatory for survival in a highly competitive global market. The Spanish hospitality sector therefore appears to be progressing adequately in terms of technology usage. However, the eWOM management task falls largely to business leaders, owners and general managers, and only minimally to hotel marketing departments. A wide variation has been found among respondents' perceptions of who is responsible for managing eWOM information in hotels. This is a matter of interest, because the utility of eWOM management needs to be supported by uniform recognition. An implication for hotel management, therefore, is the need for a strategic plan to be implemented by a capable and trained staff and for hotels to allocate financial resources to special eWOM management training. In this respect, Park and Allen (2013) recommend hotels to employ full-time staff to manage online reviews and monitor their impact on hotel performance metrics.

Moreover, the comprehensive eWIP model explains the decision-making process involved in the effective use of eWOM as a management tool from the decision maker's perspective, and, no less importantly, shows that proper eWOM management can improve 
business performance. Thus, reasoning has both a direct and an indirect influence (through global motives) on Intentions, which suggests that policymakers are largely led by their own specific reasons when forming their behavioural intentions. For the survey respondents, the main reason to use eWOM as a hotel management tool is as a means to increase profits and organize and monitor customer-retention strategies. Customer opinions are valued as part of a business-defence strategy; while attraction strategies (designed to acquire customers) are less highly valued. Nevertheless, potential customers devote plenty of time to reading online reviews in order to assist their decision-making (Zhu and Zhang 2010), and the competition among online booking platforms is so fierce that every online seller does the utmost to attract potential customers (Shuckert et al. 2015). Therefore, hotel managers should recognize the customer-acquisition potential of eWOM communication management. More training of decision-makers appears necessary for hotels to make the most of eWOM.

In addition, the direct cause-effect relationship found between eWOM and Global Motives highlights the potential of the former as a trigger of willingness to act. Credibility proves to be the least important dimension of eWOM, suggesting a perceived loss of control in the absence of no face-to-face communication. Credible information is desirable, but it is more important its usefulness and relevance, as well as its faculty to influence decisions. It should be noted at this point that as important as the honesty of the reviewers is honesty of the sellers. Preserving the good characteristics of eWOM is feasible through the implementation of filters and control systems, SEO positioning techniques could be used by hotels, for instance. Legal actions are other alternative, used mainly by sellers. Tripadvisor was sanctioned in 2014 for publishing fake reviews and other times the company has been exonerated. In line with the aforementioned results, a positive opinion by respondent about the potential of eWOM carries more weight than the influence by external agents or the perception of control over a situation. As a result, the importance of the hotel having specialized personnel trained to recognize the benefits derived from eWOM communication management is reinforced.

Customers' opinions about quality, credibility and authority indirectly influence no only the business (hotel) performance but hotel managers' future behavioural intentions. The indirect influence of eWOM on Intentions reinforces the conclusion that the inclusion of eWOM as a context variable in the model is essential. While Intentions are a consequence of Reasons, eWOM and Motives, Intentions do not depend on Performance. This is a good attitude if it means that intentions to continue using the tool are independent of any other variable, because WOM management is considered essential and, as such, contingency-independent. Even if, due to further technological innovation, "electronic" is displaced by another term, businesses will still need to manage physical and virtual communication.

In brief, it is important for hotels to provide eWOM facilities and establish effective electronic communication with customers, because this can usefully shape future management decisions. An online review response plan and operational manuals, as suggested by previous researchers (Park and Allen 2013; Kim et al. 2015), should certainly form part of the process, but it is even more important to respond through active protocols or a specialized information system as integral components of a hotel business marketing strategy. A hotel can also gain a competitive advantage by conducting its own studies, focusing on the quality of its own specific web page, evaluating the effectiveness of eWOM, and designing service-improvement proposals. 
While the research objectives have been met, this study has some limitations, which need to be addressed. Firstly, although the data adequately reflect the target population, and the sample composition is representative of the Spanish hotel industry as a whole, the results are not statistically representative of the entire population because they are based on a convenience sample and must therefore be interpreted with caution. Moreover, given that the data were collected in 2013, it is likely that the development and increasing use of technologies since that time will have affected the decision-making process, although there is no evidence of the precise impact of the most recent advances. According to Segittur (2018), virtual reality, artificial intelligence, block-chain, voice assistants and robots are shaping future trends in tourism. These novelties may well increase the efficiency of eWOM communication, and even improve the quality of interaction. For example, there is existing software for interacting with people and answering and analysing the customer's reviews; these chat-bots already allow conversational interaction with computers. Even so, experts report that technologically there is still much more to be done. According PhocusWright Research (2018), chat-bots are still rudimentary, stateless or only semi-stateful. It is time to gain more experience in the processing of conversation within the travel context, which means that technologies are being developed to assist managers as a trained and trainable staff. On the other side of the coin, there is a need to achieve a desirable degree of impartiality and transparency. In this respect, the UNWTO (2017) stresses the importance of customer review and feedback platforms taking measures to ensure that the content is useful, accurate and objective. Further research will be needed to test their acceptance, utility and level of productivity as intelligent machines capable of learning to interact with the customers.

Among future lines of research suggested by this study, we could mention testing the eWIP model in another hotel industry to strengthen the external validity of the results, potentially identify cultural differences in the management of online reviews or obtain guidelines for developing a hotel or sector (macro level). Moreover, an analysis of performance metrics, as the outcome of review management, needs to be conducted in order to measure the profit gains for the supplier (Schukert et al. 2015). It may also be interesting to explore other performance indicators in order to verify the role played by context in determining the level of co-creation (co-production that generates innovations) achieved by means of customer-company interaction through eWOM, for instance. The model could also be used as a basis for exploring different media for posting reviews and responses (hotel websites, reviewer platforms, social networks), with a view to comparing their effectiveness, and potential for supporting decision-making. Similarly, this model could support the analysis of new technology adoption processes, the acceptance of artificial intelligence, and their potential consequences.

\section{ACKNOWLEDGEMENTS}

We acknowledge the support for this research from the CREVALOR Research Group and the UZ2018-SOC-04 Research Project. 


\section{REFERENCES}

Ajzen, I., 1991. The theory of planned behaviour. Organizational Behaviour and Human Decision Processes, 50 (2), 179-211. DOI: 10.1016/0749-5978(91)90020-T.

Alam, S.S. and Sayuti, N.M., 2011. Applying the theory of planned behaviour TPB in halal food purchasing. International Journal of Commerce and Management, 21 (1), 8-20. DOI: $10.1108 / 10569211111111676$.

Albarq, A.N., 2013. Measuring the impacts of online word-of-mouth on Jordan: an empirical study. International Business Research, 7 (1), 14-22. DOI: 10.5539/ibr.v7n1p14.

Anderson, C.K., 2012. The impact of social media on lodging performance. Cornell Hospitality Report, 12 (5), 4-12.

Baka, V., 2016. The becoming of user generated reviews: Looking at the past to understand the future of managing reputation in the travel sector. Tourism Management, 53, 148162. DOI: 10.1016/j.tourman.2015.09.004.

Bansal, H.S. and Voyer, P.A., 2000. Word-of-mouth processes within a services purchase decision context. Journal of Service Research, 32, 166-77. DOI: $10.1177 / 109467050032005$.

Barclay, D., Higgins, C. and Thompson, R., 1995. The Partial Least Squares PLS approach to causal modelling: Personal computer adoption and use as an illustration. Technology Studies, Special Issue on Research Methodology, 2 (2), 285-309. DOI:10.1108/EBR10-2013-0128.

Berthon, P., Nairn, A. and Monet, A., 2003. Through the paradigm funnel: A conceptual tool for literature analysis. Marketing Education Review, 13 (2), 55-66. DOI. 10.1080/10528008.2003.11488830

Bilgihan, A., Barreda, A., Okumus, F. and Nusair, K., 2016. Consumer perception of knowledge-sharing in travel-related online social networks. Tourism Management, 52 , 287-296. DOI: 10.1016/j.tourman.2015.07.002.

Brettel, M., Mauer, R., Engelen, A. and Kupper, D., 2012. Corporate Effectuation: Entrepreneurial Action and its Impact on R\&D Project Performance. Journal of Business Venturing, 27 (2), 167-184. DOI:10.1016/j.jbusvent.2011.01.001.

Briggs, E., Peterson, M. and Gregory, G., 2010. Toward a Better Understanding of Volunteering for Nonprofit Organizations: Explaining Volunteers' Pro-Social Attitudes. Journal of Macromarketing, 30 (1), 61-76. DOI: 10.1177/0276146709352220.

Bronner, F. and De Hoog, R., 2011. Vacationers and eWOM: who posts, and why, where, and what? Journal of Travel Research, 50 (1), 15-26. DOI: 10.1177/0047287509355324

Bronner, F. and De Hoog, R., 2016. Travel websites: Changing visits, evaluations and posts. Annals of Tourism Research, 57, 94-112. DOI: 10.1016/j.annals.2015.12.012.

Camisón, C. and Villar-López, A., 2012. On how firms located in an industrial district profit from knowledge spillovers: Adoption of an organic structure and innovation capabilities. British, Journal of Management, 23, 361-382. DOI: 10.1111/j.14678551.2011.00745.x.

Camisón, C. and Villar-López, A., 2014. Organizational innovation as an enabler of technological innovation capabilities and firm performance. Journal of Business Research, 67, 2891-2902. DOI: 10.1016/j.jbusres.2012.06.004. 
Cantallops, S.A. and Salvi, F., 2014. New consumer behaviour: A research on eWOM and hotels. International Journal of Hospitality Management, 36 (January), 41-51. DOI: 10.1016/j.ijhm.2013.08.007.

Casaló, L.V., Flavian, C. and Guinaliu, M., 2011. Understanding the intention to follow the advice obtained in an online travel community. Computers in Human Behaviour, 27 (2), 622-633. DOI: 10.1016/j.chb.2010.04.013.

Chan, E.S.W., 2013. Managing green marketing: Hong Kong hotel managers' perspective. International Journal of Hospitality Management, 34 (September), 442-461. DOI: 10.1016/j.ijhm.2012.12.007.

Chen, M.F. and Tung, P.J., 2014. Developing an extended Theory of Planned Behaviour model to predict consumers' intention to visit green hotels. International Journal of Hospitality Management, 36, 221-230. DOI : 10.1016/j.ijhm.2013.09.006.

Cheng, S., Lam, T. and Hsu C., 2006. Negative Word of Mouth Communication Intention: An Application of the Theory of Planned Behaviour. Journal of Hospitality and Tourism Research, 301, 95-116. DOI: 10.1177/1096348005284269.

Cheng, V.T.P. and Loi, M.K., 2014. Handling negative online customer reviews: the effects of elaboration likelihood model and distributive justice. Journal of Travel and Tourism Marketing, 311, 1-15. DOI: 10.1080/10548408.2014.861694.

Cheung, C.M.K. and Thadani, D.R., 2012. The impact of electronic word-of-mouth communication: A literature analysis and integrative model. Decision Support Systems, 54 (1), 461-465. DOI: 10.1016/j.dss.2012.06.008

Chin, W.W., 1998. The Partial Least Squares Approach to Structural Equation Modeling, en G.A. Marcoulides [ed.]. Modern Methods for Business Research, Mahwah, N.J.: Lawrence Erlbaum Associates, Publisher, 295-336.

Claudy, M.C., Garcia, R. and O'Driscoll, A., 2015. Consumer resistance to innovation: A behavioural reasoning perspective. Journal of Academy of Marketing Science, 43 (4), 528-544. DOI: 10.1007/s11747-014-0399-0.

Confente, I., 2015. Twenty-five years of Word-of-Mouth studies: a critical review of tourism research. International Journal of Tourism Research, 17 (6), 613-624. DOI: 10.1002/jtr.2029.

Davis, F.D., Bagozzi, R.P. and Warshaw, P.R., 1989. User acceptance of computer technology: A comparison of two theoretical models. Management Science, 35 (8), 982-1003. DOI: $10.1287 / \mathrm{mnsc} .35 .8 .982$.

Di Pietro, L., Di Virgilio, F. and Pantano, E., 2012. Social network for the choice of tourist destination: attitude and behavioural intention. Journal of Hospitality and Tourism Technology, 3 (1), 60-76. DOI: 10.1108/17579881211206543.

Erkan, I. and Evans, C., 2016. The influence of eWOM in social media on consumers' purchase intentions: An extended approach to information adoption. Computers in Human Behaviour, 61, 47-55. DOI: 10.1016/j.chb.2016.03.003.

Faugier, J. and Sargeant, M., 1997. Sampling hard to reach population. Journal of Advanced Nursing, 26 (4), 790-797. DOI: 10.1046/j.1365-2648.1997.00371.x.

Filieri, R., 2015. What makes online reviews helpful? A diagnosticity-adoption framework to explain informational and normative influences in eWOM. Journal of Business Research, 68 (6), 1261-1270. DOI: 10.1016/j.jbusres.2014.11.006. 
Fishbein, M. and Ajzen, J., 1975. Belief, attitude, intention, and behaviour: An introduction to theory and research. MA: Addison Wesley.

Flavián, C., Guinalíu, M. and Gurrea, R., 2006. The role played by perceived usability, satisfaction and consumer trust on website loyalty. Information and Management, 431, 1-14. DOI:10.1016/j.im.2005.01.002.

Fornell, C. and Bookstein, F.L., 1982. A comparative analysis of two structural equation models: Lisrel and PLS applied to market data, en C. Fornell [ed.]: A Second Generation of Multivariate Analysis, New York: Praeger Publishers, 289-324.

Fornell, C. and Larcker, D.F., 1981. Evaluating structural equation models with unobservable variables and measurement error. Journal of Marketing Research, 18 (1), 39-50. DOI: $10.2307 / 3151312$.

$\mathrm{Gu}, \mathrm{B}$. and Ye, Q., 2014. First step in social media - measuring the influence of online management responses on customer satisfaction. Productions and Operations Management, 23 (4), 570-582. DOI: 10.1111/poms.12043.

Gupta, A. and Arora, N., 2017. Understanding determinants and barriers of mobile shopping adoption using behavioural reasoning theory. Journal of Retailing and Consumer Services, 36, 1-7. DOI: 10.1016/j.jretconser.2016.12.012.

Hennig-Thurau, T., Gwinner, K.P., Walsh, G. and Gremler, D.D., 2004. Electronic wordof-mouth via consumer-opinion platforms: What motivates consumers to articulate themselves on the Internet?. Journal of Interactive Marketing, 18 (1), 38-52. DOI: $10.1002 /$ dir.10073.

Horwath, H.T.L (2018). European Chains \& Hotels Report 2018. Available from https:// corporate.cms-horwathhtl.com/wp-content/uploads/sites/2/2018/11/HHTL_2018-EUCHAINS-REPORT.pdf

Hsu, C.H.C., Kang, S.K. and Lam, T., 2006. Reference group influence among Chinese travellers. Journal of Travel Research,44,474-484. DOI: 10.1177/0047287505282951.

Huang, M., Cai, F., Tsang, A.S.L. and Zhou, N., 2011. Making your online voice loud: the critical role of WOM information. European Journal of Marketing, 45 (7/8), 1277 1297. DOI: $10.1108 / 03090561111137714$.

INE, Instituto Nacional de Estadística 2014. Encuesta de ocupación hotelera 2013; Available from https://ine.es [Accessed 15 November 2015].

Jalilvand M.R. and Samiei N., 2012. The impact of electronic word of mouth on a tourism destination choice: testing the theory of planned behaviour. Internet Research, 22 (5), 591-612. DOI: 10.1108/10662241211271563.

Jalilvand, M.R., Samiei, N., Dini, C. and Manzari, P.Y., 2012. Examining the structural relationships of electronic word of mouth, destination image, tourist attitude toward destination and travel intention: An integrated approach. Journal of Destination Marketing and Management, 1 (1/2), 134-143. DOI:10.1016/j.jdmm.2012.10.001.

Kim, S. and Park, H., 2013. Effects of various characteristics of social commerce s-commerce on consumers'trust and trust performance. International Journal of Information Management. 33 (2), 318-332. DOI: 10.1016/j.ijinfomgt.2012.11.006.

Kim, T.G., Lee, J.H. and Law, R., 2008. An empirical examination of the acceptance behaviour of hotel front office systems: An extended technology acceptance model. Tourism Management, 29, 500-513. DOI: 10.1016/j.tourman.2007.05.016. 
Kim, W.G., Lim, H. and Brymer, R.A., 2015. The effectiveness of managing social media on hotel performance. International Journal of Hospitality Management, 44, 165-171. DOI: $10.1016 /$ j.ijhm.2014.10.014.

Kraft, P., Rise, J., Sutton, S. and Roysamb, E., 2005. Perceived difficulty in the theory of planned behaviour: Perceived behavioural control or affective attitude? British Journal of Social Psychology, 44, 479-49. DOI: 10.1348/014466604X17533.

Liang, R.D. and Lim, W.M., 2011. Exploring the online buying behaviour of specialty food shoppers. International Journal of Hospitality Management, 30 (4), 855-865. DOI:10.1016/j.ijhm.2011.01.006.

Litvin, S.W. and Hoffman, L.M., 2012. Responses to consumer-generated media in the hospitality marketplace: an empirical study. Journal of Vacation Marketing, 18 (2), 135-145. DOI: $10.1177 / 1356766712443467$.

Litvin, S.W., Goldsmith, R.E. and Pan, B., 2008. Electronic Word of Mouth in hospitality and tourism management. Tourism Management, 29, 458-468. DOI: 10.1016/j.tourman.2007.05.011.

Liu, Z. and Park, S., 2015. What makes a useful online review? Implication for travel product websites. Tourism Management, 47 (April), 140-151. DOI: 10.1016/j.tourman.2014.09.020.

Lu, W. and Stepchenkova, S., 2012. Ecotourism experiences reported online: classification of satisfaction attributes. Tourism Management, 33 (3), 702-712. DOI: 10.1016/j.tourman.2011.08.003.

Marpsat, M. and Razafindratsima, N., 2010. Survey Methods for Hard-to-Reach Populations: Introduction to the Special Issue. Methodological Innovations Online, 5 (2), 3-16. DOI: 10.4256/mio.2010.0014.

Martin, D.S., Ramamonjiarivelo, Z. and Martin, W.S., 2011. MEDTOUR: a scale for measuring medical tourism intentions. Tourism Review, 66 (1/2), 45-56. DOI: 10.1108/16605371111127233.

Martin, W.C. and Lueg, J.E., 2013. Modeling word-of-mouth usage. Journal of Business Research, 66 (7), 801-808. DOI: 10.1016/j.jbusres.2011.06.004.

Mauri, A.G. and Minazzi, R., 2013. Web reviews influence on expectations and purchasing intentions of hotel potential customers. International Journal of Hospitality Management, 34, 99-107. DOI: 10.1016/j.ijhm.2013.02.012.

Miao, Y., 2015. The Influence of Electronic-WOM on Tourists' Behavioural Intention to Choose a Destination: A case of Chinese Tourists Visiting Thailand. AU-GSB e-Journal, 8 (1), 13-31. Available from http://www.assumptionjournal.au.edu/index.php/AUGSB/article/viewFile/1453/1277 [Accessed 15 January 2014].

Nunnally, J.C., 1978. Psychometric Theory, 2a ed. McGraw-Hill, Nueva York, 701.

O'Driscoll, A., Claudy, M. and Peterson, M., 2013. Understanding the Attitude-Behaviour Gap for Renewable Energy Systems Using Behavioural Reasoning Theory. Journal of Macromarketing, 33 (4), 273-287. DOI: 10.1177/0276146713481605.

Park, M., Cho, H., Johnson, K. P. and Yurchisin, J., 2017. Use of behavioural reasoning theory to examine the role of social responsibility in attitudes toward apparel donation. International Journal of Consumer Studies, 41, 333-339. DOI: 10.1111/ijcs.12347. 
Park, S.Y., and Allen, J.P., 2013. Responding to online reviews: problem solving and engagement in hotels. Cornell Hospitality Quarterly, 54 (1), 64-73. DOI: $10.1177 / 1938965512463118$.

Phillips, P., Zigan, K., Santos Silva, M.M. and Schegg, R., 2015. The interactive effects of online reviews on the determinants of Swiss hotel performance: A neural network analysis. Tourism Management, 50, 130-141. DOI: 10.1016/j.tourman.2015.01.028.

PhocusWright Research, 2018. Report of September, 2018. Available from www.phocuswright.com [Accessed 15 November 2018].

Rieh, S.Y., 2002. Judgment of information quality and cognitive authority in the web. Journal of the American Society for Information Science and Technology, 53 (2), 145-161. DOI: 10.1002/asi.10017.abs.

Rieh, S.Y., 2010. Credibility and cognitive authority of information. In M. Bates and M. N. Maack Eds. Encyclopedia of Library and Information Sciences, 3rd Ed. 1337-1344, New York: Taylor and Francis Group, LLC.

Riemenschneider, C.K., Harrison, D.A. and Mykytyn, P.P., 2003. Understanding IT adoption decisions in small business: integrating current theories. Information and Management, 40, 269-85. DOI: 10.1016/S0378-7206(02)00010-1.

Ryan, J. and Casidy, R., 2018. The role of brand reputation in organic food consumption: A behavioural reasoning perspective. Journal of Retailing and Consumer Services, 41, 239-247. DOI: 10.1016/j.jretconser.2018.01.002.

Schuckert, M.; Liu, X. and Law, R., 2015. Hospitality and tourism online reviews: recent trends and future directions. Journal of Travel and Tourism Marketing, 32 (5), 608-621. DOI: $10.1080 / 10548408.2014 .933154$.

SEGITTUR 2018. Turismo e innovación. Gobierno de España. Available from https:// www.segittur.es/ [Accessed 5 December 2018].

Sigala, M., 2013. Measuring customer value in online collaborative trip planning processes. Marketing Intelligence and Planning Processes, 28 (4), 418-443. DOI: 10.1108/02634501011053559.

Sparks, B.A. and Browning, V., 2011. The impact of online reviews on hotel booking intentions and perception of trust. Tourism Management, 32 (6), 1310-1323. DOI: 10.1108/ IJCHM-12-2013-0542.

Sun, T., Ayoun, B. and Calhoun, J. 2013. The effect of organizational commitment on Word-of-Mouth intentions in recruitment in China. Journal of Human Resources in Hospitality \& Tourism, 12 (2), 192-216. DOI: 10.1080/15332845.2013.752711.

Teng, Y.M., Wu, K.S. and Liu, H.H., 2014. Integrating altruism and the theory of planned behaviour to predict patron age intention of a green hotel. Journal of Hospitality and Tourism Research, 39 (3), 299-315. DOI: 10.1177/1096348012471383.

TOIS 2014. Telecommunication Observatory and Information Society. Perfil sociodemográfico de los internautas. Análisis de datos INE 2013. Available from http:// www.ontsi.red.es/ontsi/sites/ontsi/files/perfil_sociodemografico_de_los_internautas_2013_0.pdf [Accessed 16 November 2014].

UNWTO. United Nations World Tourism Organization, 2017. 3rd International Congress on Ethics and Tourism. Enhancing the sector' sustainability through shared responsibilities. 27,28 April. Krakow Poland. Available from http://media.unwto.org [Accessed 5 December 2018]. 
Venkatesh, V. and Davis, F.D., 1996. A model of the antecedents of perceived ease of use. Development and test. Decision Sciences, 27 (3), 451-481. DOI: 10.1111/j.15405915.1996.tb00860.x.

Venkatesh, V. and Davis, F.D., 2000. A theoretical extension of the Technology Acceptance Model: Four longitudinal field studies. Management Science, 46 (2), 186-204. DOI: 10.1287/mnsc.46.2.186.11926.

Venkatesh, V., Morris, M., Davis, G. and Davis, F., 2003. User acceptance of information technology: toward a unified view. MIS Quarterly, 27, 425 - 478. DOI: 10.2307/30036540.

Wangenheim, F.V. and Bayon, T., 2004. The effects of word of mouth on services switching: measurement and moderating variables. European Journal of Marketing, 38 (9/10), 1173-1185. DOI: 10.1108/03090560410548924.

Wei, W., Miao, L. and Huang, Z., 2013. Customer engagement behaviours and hotel responses. International Journal of Hospitality Management, 33 (June), 316-330. DOI: 10.1016/j.ijhm.2012.10.002.

Westaby, D.J., Probst, T.M., and Lee, C.B., 2010. Leadership decision-making: a behavioural reasoning theory analysis. Leadership Quarterly, 21(3), 481-495.

Westaby, J., 2005. Behavioural reasoning theory: Identifying new linkages underlying intentions and behaviour. Organizational Behaviour and Human Decision Processes, 98 (2), 97-120. DOI: 10.1016/j.obhdp.2005.07.003.

Wold, H., 1985. Systems under indirect observation using PLS. C. Fornell ed.: A Second Generation of Multivariate Analysis, 1, 325-347. New York: Praeger Publishers.

Xie, K., Kam Fung So, K. and Wang, W., 2017. Joint effects of management responses and online reviews on hotel financial performance: A data-analytics approach. International Journal of Hospitality Management, 62, 101-110. DOI: 10.1016/j.ijhm.2016.12.004.

Xie, K.L., Zhang, Z., Zhang, Z., Singh, A. and Lee, S.K., 2016. Effects of managerial response on consumer eWOM and hotel performance: evidence from Tripadvisor. International Journal of Contemporary Hospitality Management, 28 (9), 2013-2034. DOI: 10.1108/IJCHM-06-2015-0290.

Ye, Q., Law, R., Gu, B., 2009. The impact of online user reviews on hotel room sales. International Journal Of Hospitality Management, 28 (1), 180-182. DOI: 10.1016/j. ijhm.2008.06.011.

Ye, Q., Law, R., Gu, B., Chen, W., 2011. The influence of user-generated content on traveler behavior: an empirical investigation on the effects of e-word-of-mouth to hotel online bookings. Computers in Human Behavior, 27 (2), 634-639. DOI: 10.1016/j. chb.2010.04.014.

Yu, J., Ha, I., Choi, M. and Rho, J., 2005. Extending the TAM for a t-commerce. Information and Management, 43 (3), 965-976. DOI: 10.1016/j.im.2004.11.001.

Zhu, F. and Zhang, X., 2010. Impact of online consumer reviews on sales: the moderating role of product and consumer characteristics. Journal of Marketing, 74 (2), 133-148. DOI: $10.1509 / j m k g .74 .2 .133$. 